tITLE: SHUTTLRING EFFICIENCIES OF NANOSECOND-GATED PHOTOEMISSIVE SHUTTBR TUBES

LA-OR--85-2743

AUTHON8): George J. Yates and Steven A. Jaramillo Thomae S. Pagano and J. Paul Black

\section{D.85 015728}

\author{
QUEMITTED TO: 1985 SPIE \\ San Diego, CA \\ Auguet 19-23, 1985.
}

\title{
DECLAMMR:
}

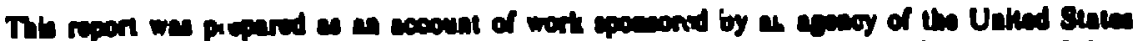

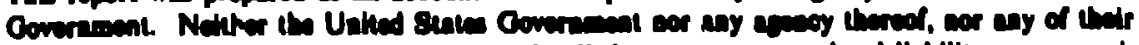

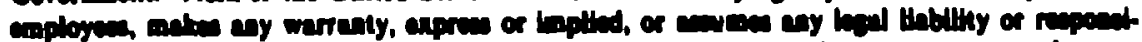

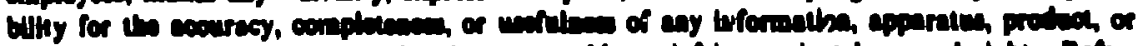

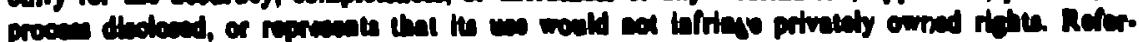

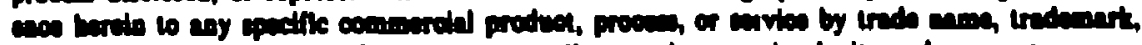

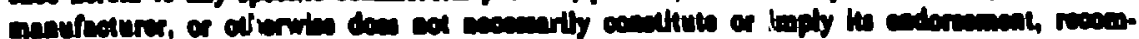

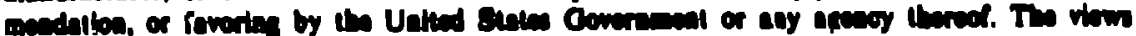

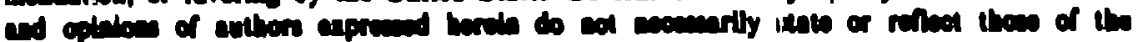

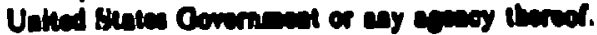


shuttering efficienoles of nanosecond-gated photooniesive shutter tubes

Coorge J. Yates and steven A. Jaramillo

Phyales Divielon, OnIveraity of Callfornla, Los Alamos, Rational Laboratory Group P-15, Mali 8top D406, P.0. Box 1663, Los Alamos, Now Maxico B7545

and

Thonas 8. Pagano and J. Paul Black

EQSG Inc., Eneray Meaeurement. Divialon

Santa Barbara Operatione and Kirtland Operatione

\begin{abstract}
Abetract
Reoent atudies whow that effective shuttering of photoemisalve tuber, euch as siliconIntenaifled-Target Vidische (SITVe) and Mlerochannel-plate Image Intenaifler Tubes (MCPTo), can vary widely dopending upon the extent of their opacity to an 1 nput flux of photone. Optical feedthrough algnals from photon tranamiesion through the photocathode to the target

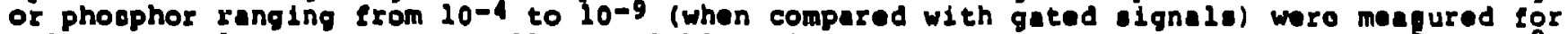
- large eampling of commorically avallable unite. Effective chutter ratios of $10^{5}$ to $10^{8}$ measured for unite operated in quiescently derk onvironmente can be oubstantially reduced by optical feedthrough. Furthermore, Inef fective uppression of photoemiealon can cause further reductions in hutter ratio. Reductions are -oughly correlated with the ratio of optleal gate duration to light pulse duration. Expar. mentation with various thicknesees of luminum depositions on MCPT phosphors and chromium layering on 5 ITV allicon targete Indicate substantial reductions (2x to $15 \%)$ in tranemission with minimal increases in threchold volteges required for gein. These reeults, together with exploratory studies of external coating of output tiber optice with tranamiasion filtera apactraliy matched to minimize leedthrough to P-20 phosphors are reported.
\end{abstract}

\title{
Introduction
}

In many appllcatione thege shutfer tubes are exposin to transient optlcal scenes that vary in intenalty over a 105 to $10^{6}$ dynamic range and peralet eeveral orders of magnitude longer then the shutter perlod. To linearly record the image intenalty at varlous times throughout weh light Impulses requires taof shutter gate response and an extinetion ratio outelde the optlcal gate of greater than 106 . For this type of shutter, two shutter ration exiet, (1) photon ohutter ratio cauped by the unintended transmiseion of 1 nput flux from the photoacthode to the target and (2) ejectron ohutter ratio which is the effectivenese of the reverae bias electric field in euppreseing photocathode emiseion.

Eardler we reported' maximum dynamic or gated ohutter ratior of $>10^{7}$ for MCPTa and $\approx 10^{3}$ tor BITVe opereted in a derk environment and etimulated with delta Function impulees of light 1500 pe FHM light pulees time-phesed to colnolde with 5 ne optlcal gatee). Refinemonte of those measuremente show that ahutter ratios also vary with (1) .uagnitude of reverse blas uead for uppresesion of photocathode amiseion and (2) magnitude of MCP or SIT galn during gate time. These effect, oombined wlth the Integrated eftecta from optical feedthrough in tleld applications where these unite are coupled to light onaltive devices (the allicon target for $8 I T V e$ and $111 \mathrm{~m}, B_{3} s_{3}$ vidicone, CCDe, or CIDe for MCPTE) wlth bruad opeotral roopnnees makjng it diflioult to diotinguieh between algnale produced trom tranemitted light and those produced from photoelectrons are diecuesed.

\section{Opaeity meaguremente}

We reported'il photon onutter ratios for gated BITVe earller. Recently we oboerved almilar probleme for MCPTs. The opacity for eeveral eamples was meacured by ueing a broadband CW lamp to 11 iuninate the photoosthode while monitoring the phosphor with a radiometer. The experimontel oet-up is show in Flg. 2. The Cw lamp (Amerioan Optlond Model 263 with mlerosoope Ienel we loouted 6-1/2 inohes from the MCPT photooathode. A $1-c m^{2}$ clrcular aperture wa used to makk the MCPT photocathode so that ite diluminated area would be equal to the input aperture for the coso model 350 iadiomoter.

The 11ght penetrating the phoophor wa moasured with the radiometer eampling hoad butted dreotly agalnet the MCPT output elber opile while the photooathode was expoed.

The optloal energy of the CW lamp (labeled Input Energy in Table I) was maeured at the MCPT photocathode plene by removing the MCPT and positioning the radioneter senaling head at 
the ane location. A neutral density gelatin filter, ND 4.0, wee Ineerted between the CN source and the radiometer to attenuate the input ilght to a levol compatible with the dynamic range of the radiometor. The table ontries are actual readinge cerrected upyard by $10^{4}$ to ecoilnt for the eories ND. The average optical power deneity was $\approx 200 \mathrm{~m} / \mathrm{cm}^{2}$ lor this date sot. The wavelength opectrum, mesured WIth a LI-COR model II-I000 opectroneter

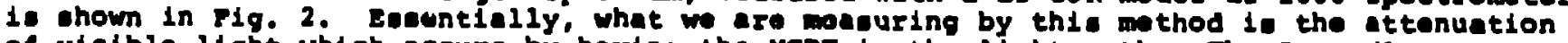
of vialble light which occurs by having the MCPT in the ilght peth. The Input/Output colume of Table I show the attenuation factor or optical ahuter ratio for the MCPT. Thood attanuation data converted to equivalent trananiasion are Date set I in Table II.

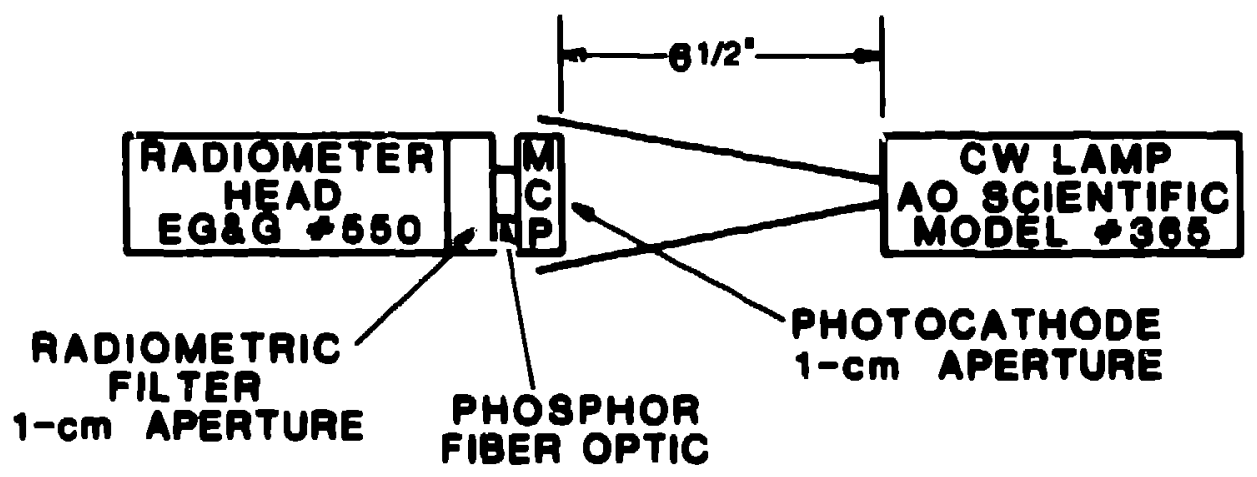

\section{VISIBLE PHOTON TRANSMISSION TEST SET-UP}

Fig. 1. The opacisy meesurament setup

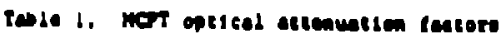

\begin{tabular}{|c|c|c|c|c|}
\hline \multicolumn{2}{|c|}{ Sonureeturor sx } & \multirow{2}{*}{ 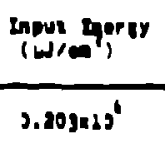 } & \multirow{2}{*}{$\frac{\text { readurewgh }}{0.90 \mathrm{~m} 2 g^{-1}}$} & \multirow{2}{*}{ 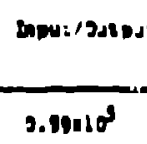 } \\
\hline$\pi$ & rex/6 & & & \\
\hline$\cdot$ & $071 / 1$ & $0.213110^{\circ}$ & 0.rotulio-1 & 0.201 .00 \\
\hline - & $039 / 11$ & $0.10 m+6$ & $0.150119^{-1}$ & $1.10 \times 10^{\circ}$ \\
\hline - & 7071 & $0 . \operatorname{cas} 10^{4}$ & $0 . \operatorname{senes10^{-1}}$ & $0.0010^{9}$ \\
\hline - & $16110 / 1$ & $0.10 \mathrm{~m} 10^{4}$ & $0.181110^{-3}$ & 1.enng' \\
\hline - & 16-100/19? & $0.103+17 x$ & $0.039=10^{-1}$ & 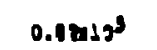 \\
\hline - & wo/l & $0.10281)^{4}$ & $0.40110^{-1}$ & $0.0 \mathrm{men}$ \\
\hline - & 02916 & $0.280 .10^{\circ}$ & $0.28 n+10^{-1}$ & $1 . \mathrm{Mnd} \mathrm{g}^{3}$ \\
\hline - & $\ln / 1$ & $0,193810^{4}$ & 0. anesio-? & $0 . \mathrm{min})^{0}$ \\
\hline - & $930 / 11$ & $0.178+10^{4}$ & $0.400110^{-1}$ & $0.87110^{\circ}$ \\
\hline - & |LIII/) & $0.178 \times 10^{4}$ & 0. nieiget & $0 . \operatorname{lan} 25^{\circ}$ \\
\hline - & 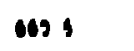 & $0.17 m i d g^{\circ}$ & $0.4 \pi+12^{-1}$ & '. \\
\hline$"$ & $14-111 / 4$ & $1.2 \mathrm{n} 10^{3}$ & $0.38=40^{-1}$ & 1.9100 \\
\hline veno & n09031 & $0.193 n 1 g^{4}$ & $0.04011^{-1}$ & 1.4018.' \\
\hline • & $\log 311$ & $2.19011)^{4}$ & 0.95211 & $1.19 \times 190$ \\
\hline$"$ & colls & 9.11Radot & $0.20712,01$ & $1.69110^{\circ}$ \\
\hline - & 108991 & o.2Thet & $0.049+1 g^{-1}$ & $0 .+n 10^{7}$ \\
\hline - & (253II & $9.19 \mathrm{n}$ - & O.Misis-J & $0.79 n 197$ \\
\hline$\cdot$ & nosin1 & $0,213+1,4$ & $9.094110^{-1}$ & $3.131 n^{\prime}$ \\
\hline - & mal & $2,101 \mathrm{at} \mathrm{g}^{4}$ & $0.0991 g^{-1}$ & P.muln' \\
\hline
\end{tabular}

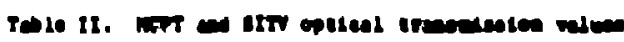

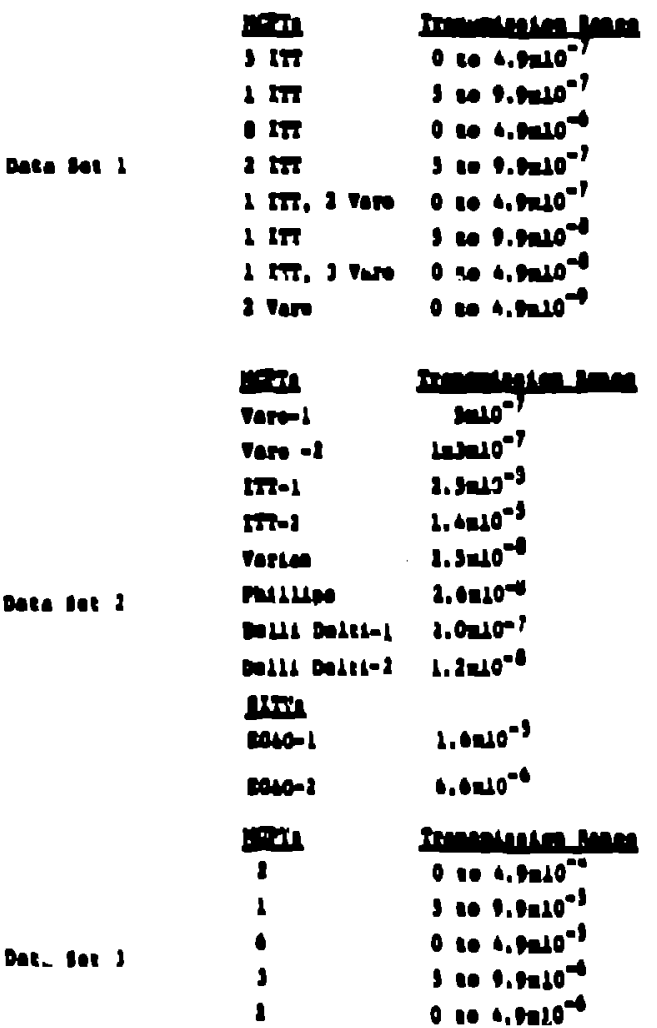




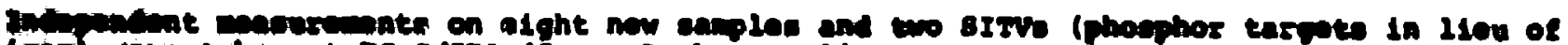

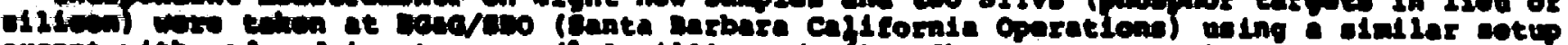

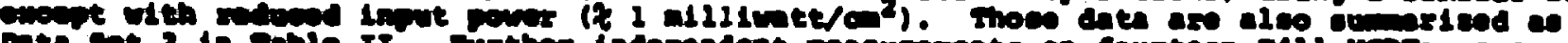

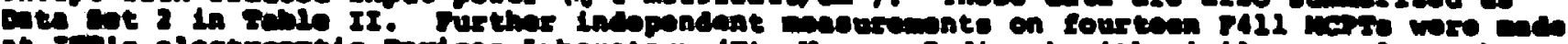

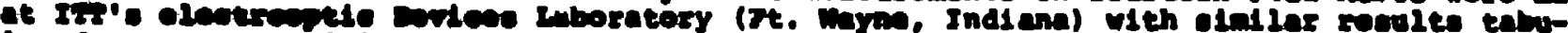
lated ac ber got 3 in toblo II.

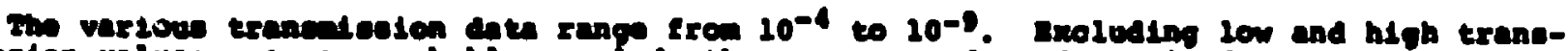

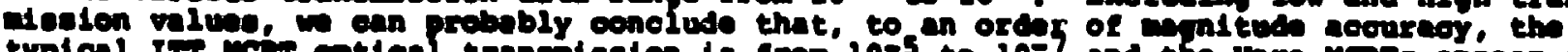

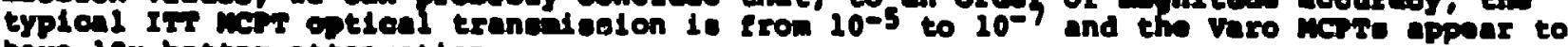
haw $10 x$ betear ateanuetion.

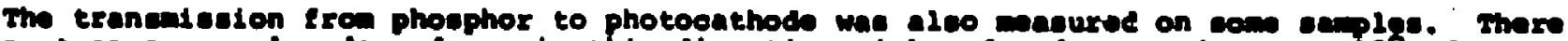

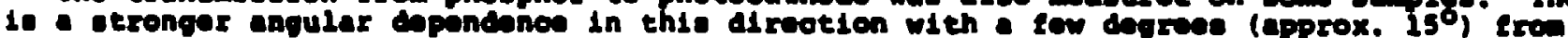

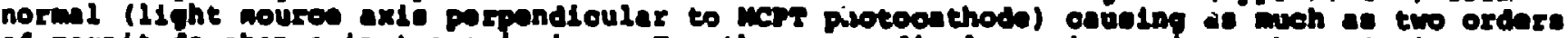
of megnitude ohange in tranenibeion. For the porpendivular orienteclon, the wajority of

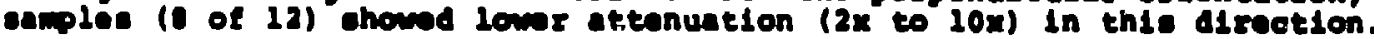

Experibentetion with varlous thioknossed of aluatnu oxide phoophor ooating to ifprove

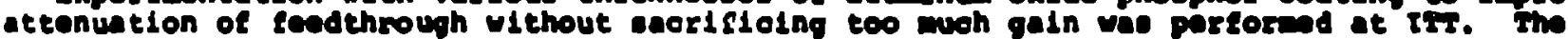

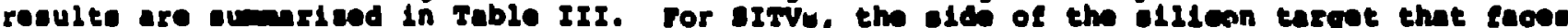

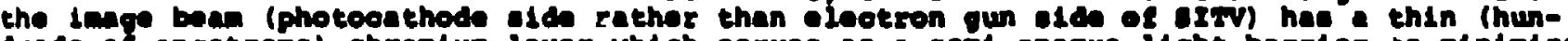

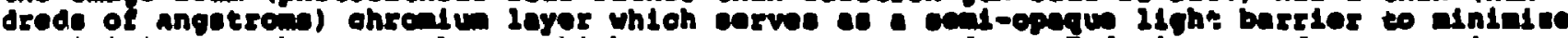

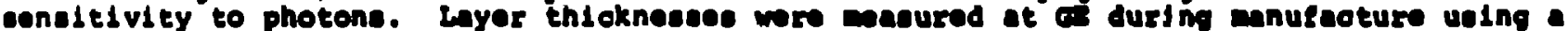
quarte orybtal osolilator and anelysing resonanees. The date for 3 fITVo lo in Trole III.

Table III. MCPT and 8ITV tranamieaton ve target coating thioknese

\begin{tabular}{|c|c|c|c|c|}
\hline & $\begin{array}{l}\text { Approximats } \\
\text { minloknee (i) }\end{array}$ & $\begin{array}{c}\text { trantulasion } \\
\text { (Coating+tqt+fo ooupler) }\end{array}$ & dend yoltere & renarky \\
\hline Normal & -- & $3 \times 10^{-3}$ & $3 \mathrm{KV}$ & $-\infty$ \\
\hline let ettompti & -- & $4 \times 10^{-4}$ & - & A1 11eted upon \\
\hline 2nd attempt? & - & $6 \times 10^{-4}$ & $3.4 \mathrm{xV}$ & $\begin{array}{l}\text { Uaed on onl } 4-312 / 4 \\
\text { neD nCTr. }\end{array}$ \\
\hline 3rd attorpt I & $-\infty$ & $1.5 \times 10^{-3}$ & $3.7 \mathrm{KV}$ & $\begin{array}{l}\text { Mot yot teoted in } \\
\text { MCPr geometry. }\end{array}$ \\
\hline $\begin{array}{l}\text { 8ITV-1 } \\
\text { BITV-2 } \\
\text { 8ITV-3 }\end{array}$ & $\begin{array}{r}100 \\
200 \\
700\end{array}$ & $\begin{array}{ll}x & 200 \\
2 & 10 \\
< & 20\end{array}$ & $\begin{array}{rl}3 & K V \\
3 & K V \\
3.5 & K V\end{array}$ & $=$ \\
\hline
\end{tabular}

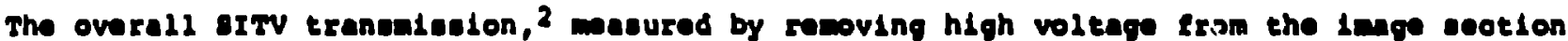

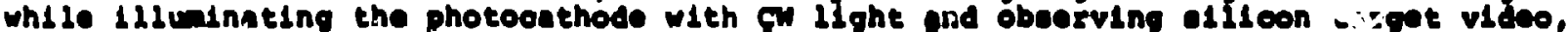

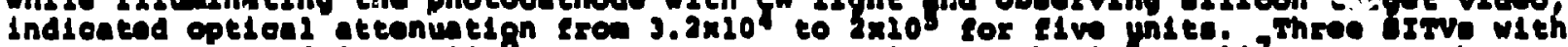
ohromiu in the 000 to $000 X$ range geve ateenuation in the 10 to 207 range. The posolbs11ty of externaliy oosting MCT output (phosphor) tiber optlo couplere with marrer band

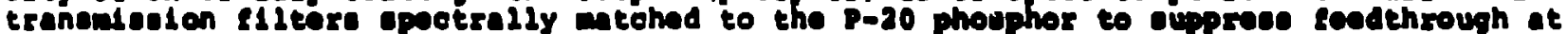

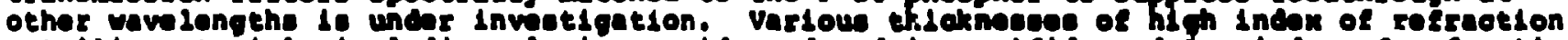

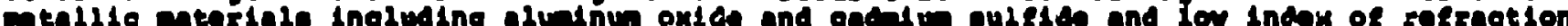

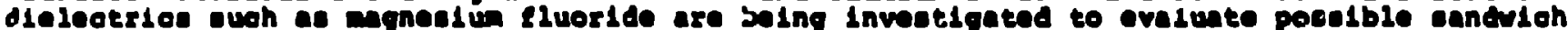

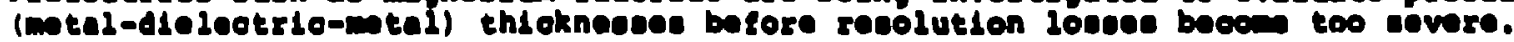

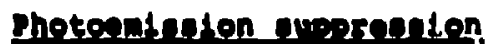

The phoophor brtentmes a a funetion of photoeathode-to-mleroohannel plete yoltage wae

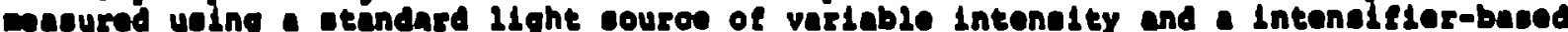

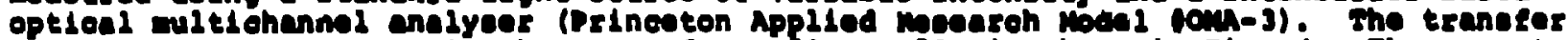

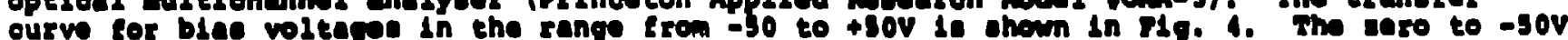

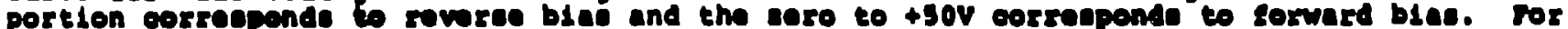

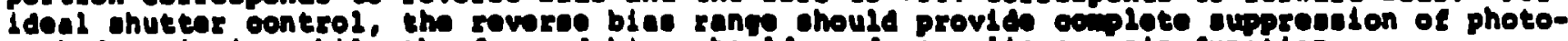

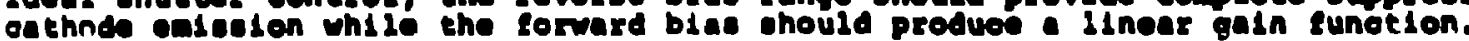

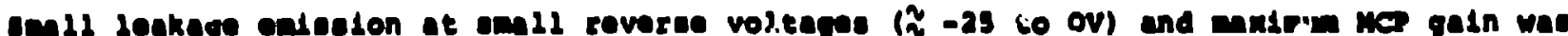
observed tren ol ther varo or Ifr unite. This was unoupooted dnause the energy range of

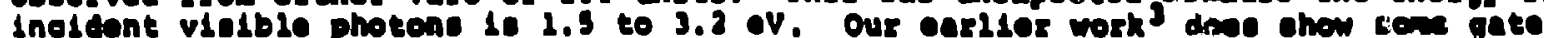

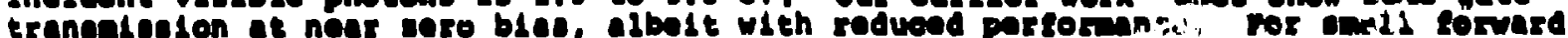

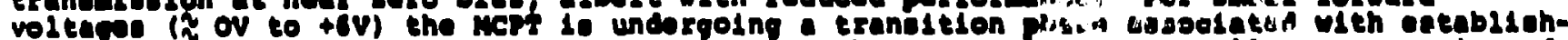

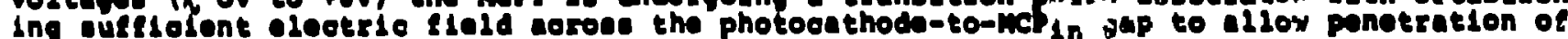




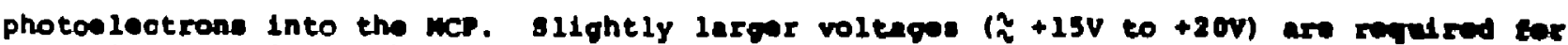
proxinity focwing to be establiehod. Byond $+20 \mathrm{v}$, gain inoresen limearly vith volten and resolution showe only a reak dependenoe on voltege.

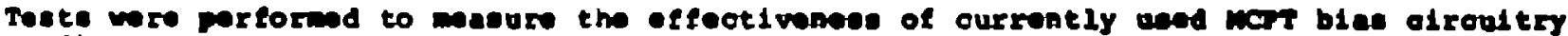

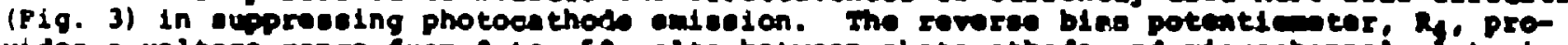

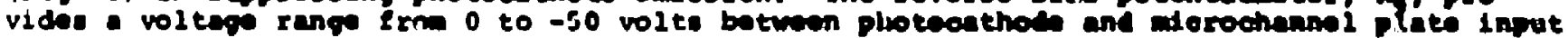

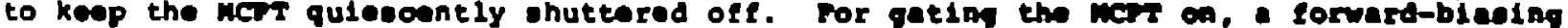

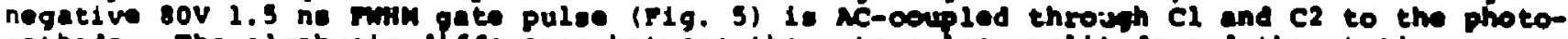
cathode. The algebraic alfference between the gate pulee applitude and the etatio raverae blas le the effeotive lorward blac voltege as indiceted in Flo. 6.

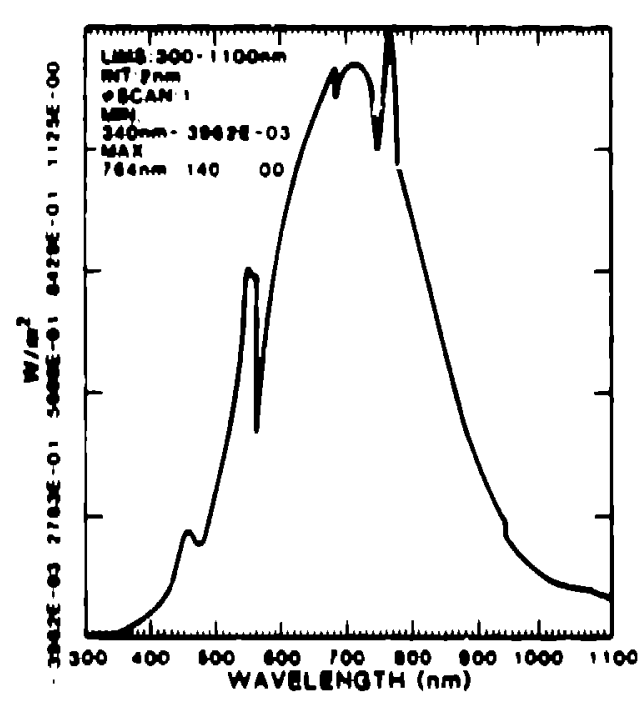

Flg. 2. Spectrum of CH souroe used for opactity experiments.

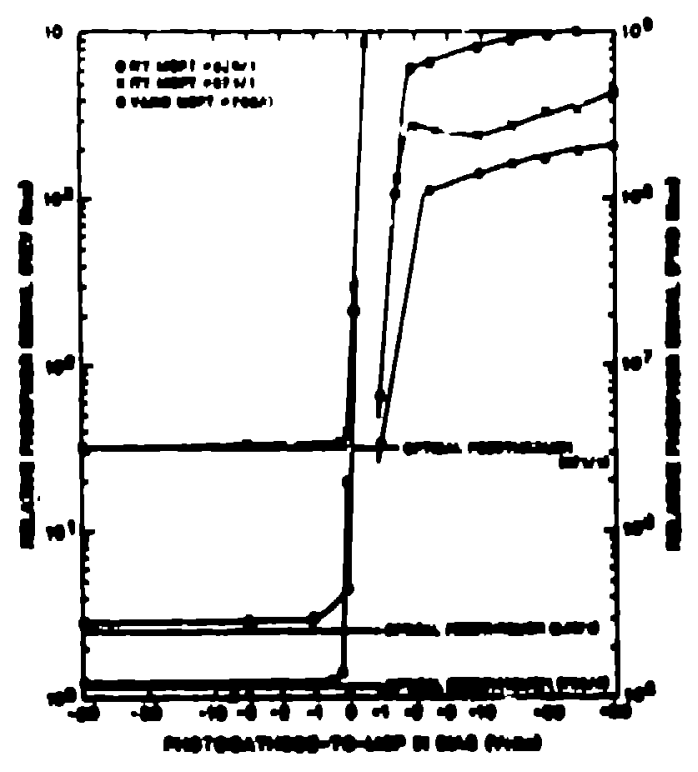

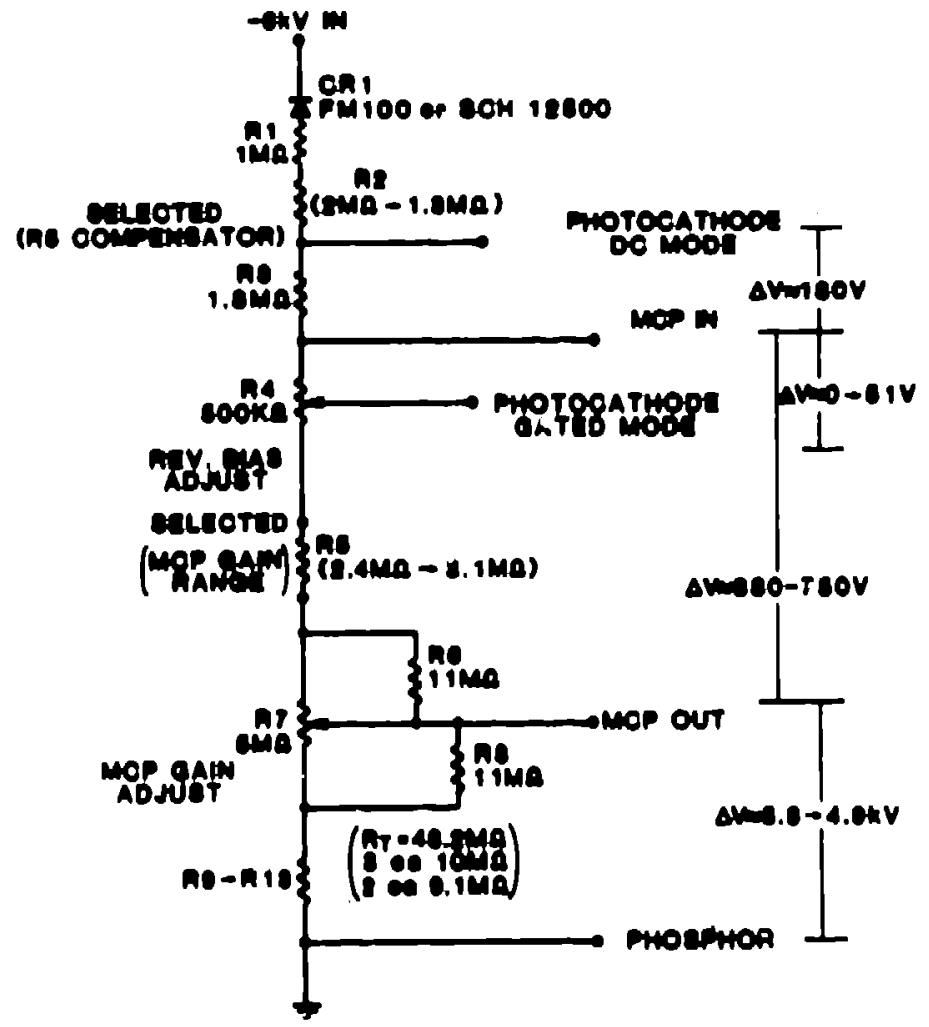

BCHEMATIC FOA 100 MA MCPT HY OIVIDEA

F1g. 3. High voltage divlder alroult used tor biasing MCPTe. Voltages show are masured values under load vith MCPT In the dark.

1

F19. 4. MCrt phoophor optlosl energy versine photooethode-ts MCP in blae for constent input intenolty. 


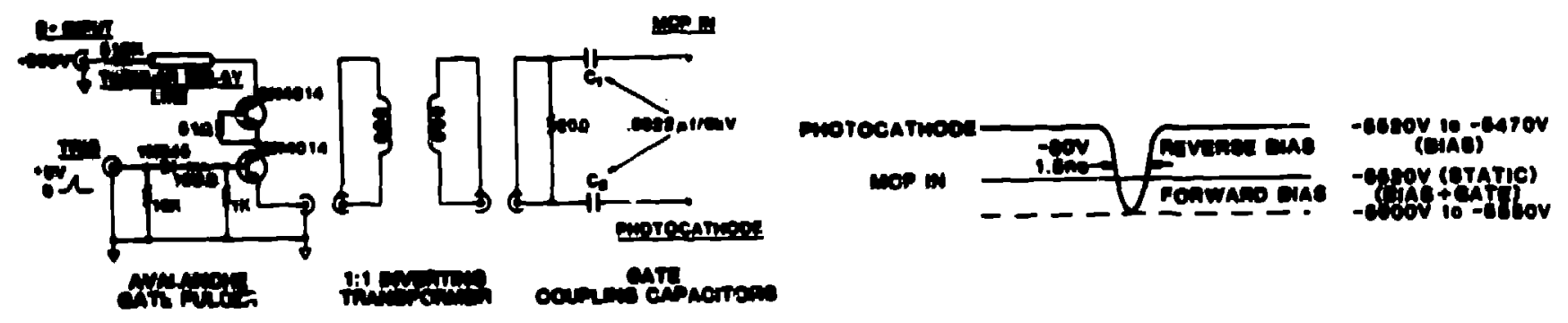

Fig. 5. Avalanche gate puleer for gating MCPT.

Fig. 6. Blases eotabliehed by combining divider and puleer circuita.

Two standerd conflguration KCPTe, ITT F4111 and Vero5722-II were operated in the AC or gated mode (non-gated phame) with high voltage applied but with 10 gate puleo so the tube should be huttered off over the range of reverse bies provided by $R_{4}$. The MCPT was then atrobed with a high intenelty ahort duration Xenon Ilach (see F1g. 7 ) and the phosphor algnal was recorded by an $\mathrm{Sb}_{2} \mathrm{~g}_{3}$ PPS vidicon flber optically coupled to the MCPT. The urias of video ccan-iline photographe in Fig. $B$ how that when the MCPT and phomphor have volteges acrose them (both are active and raady to provide gain for any electrons that reach them) the laakase photoemisolon is amplified oven though the MCPT if aeumed to be off and no gate pulce is applied. The varo unit appeared to be lase effectively biased (allowed more leakago photomisalon) than the ITT unit, ae indicated by the larger ND flitere required to give the came amplitude as for the optical feedthrough algnal.

Bucauee of gain, the difference in gated or DC mode elgnal amplitude ve optical throughput with no HV lo graater (by an amount equal to the gain of the tube) than the optlcal chutter ratio. This 10 also shown if Fig., F. For typisal ITT and Varo units, the DC mode - lgnal for Max MCP gain is erom 1010 to $1011^{\circ}$ etronger than the optical fepdthru. Fer these -am MCPIs, the optical shutter ratio 10 from 106 to 107 .

The gajn dependence on reverse blas was further analyaed ueing the setup ohown 111 Fig. 9. An EGGG 550 jadiometer was uned to masure phosplior brijntnese at the center of the optlcal gate at several ro iree bias voltages witr. flxed gate amplitucie (refer to Figs. 5-7 for clarification of aciual division between forward and reverse blaces). The plota for two different MCPTA, ITT SN 24-311/4 and varo SN 324054 are found in Fig. 10. Again, the ITT unit appears to be more effectively blaned off than the varo unit at lower reverae-bias settings.

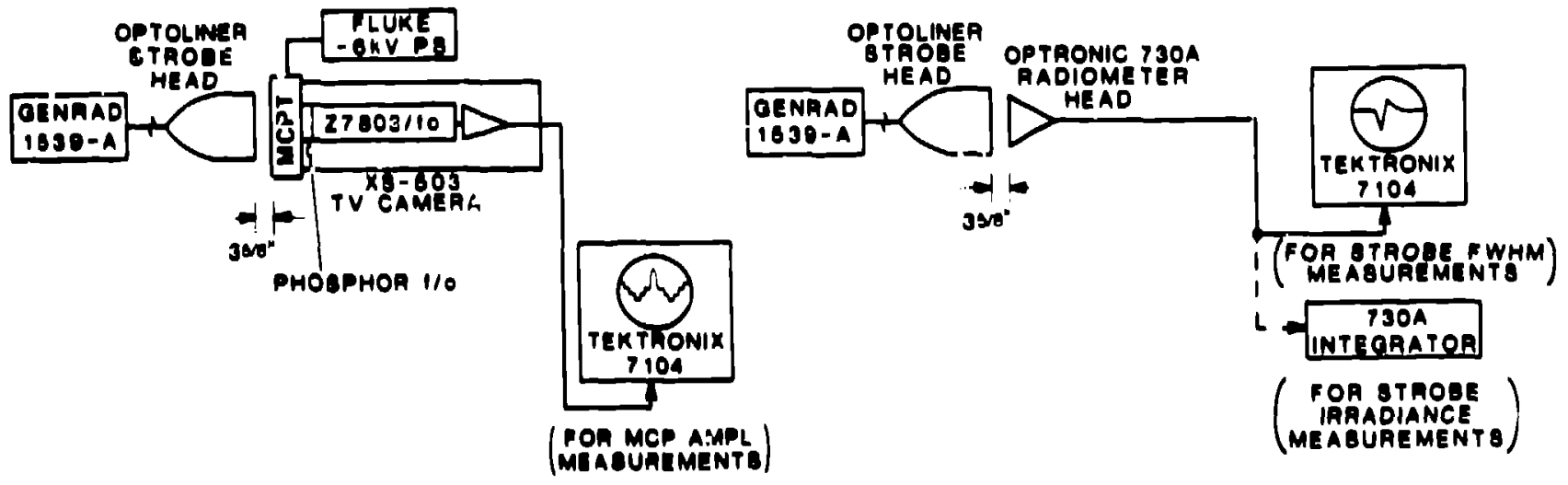

PHOTON/ELECTRON SHUTTER RATIO TEBT BET-UF

F19. 7. Sutup for photocathode leakage emienion experiment. The light eource 10 a General Radio Btrobe, Model $1539-A$. The vidicon coupled to the MCPT phosphor measures phouphor algnal lnduced by photoelectrone which ere not uppresued by the reverse bies. 


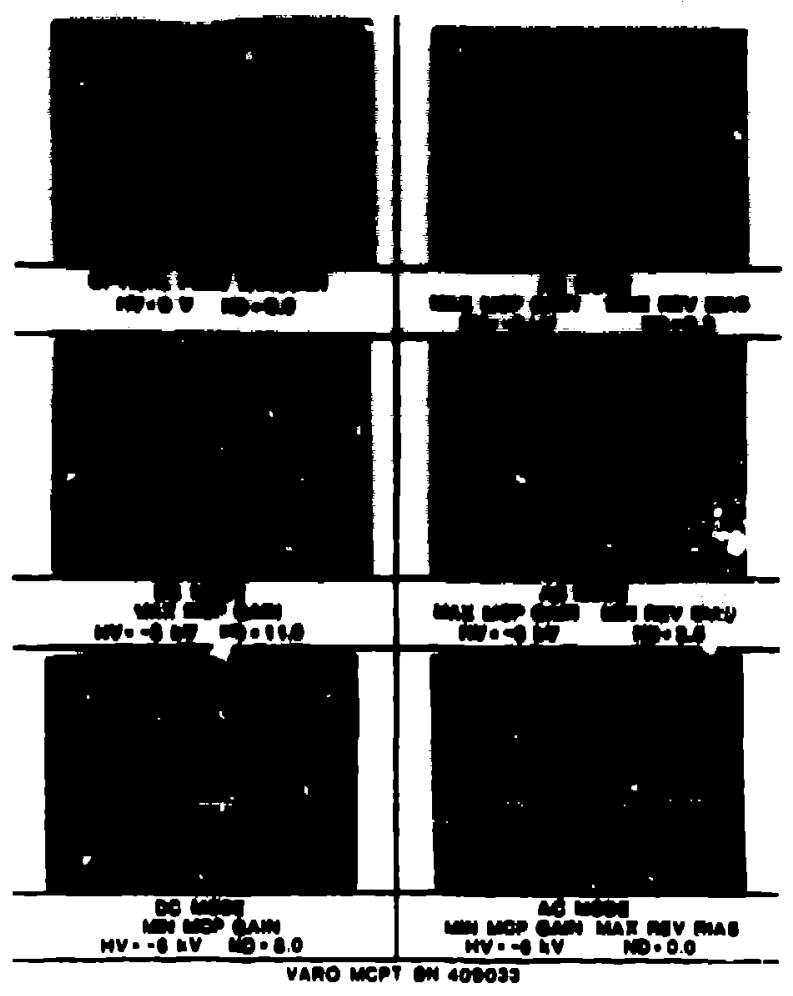

a

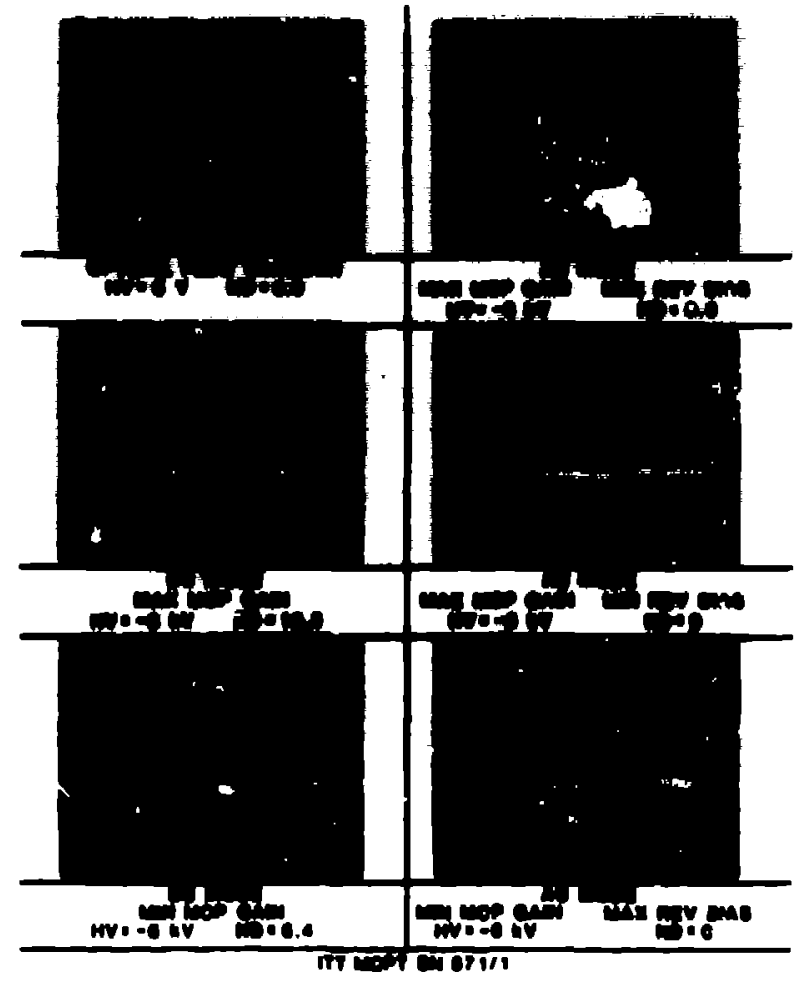

$\mathbf{b}$

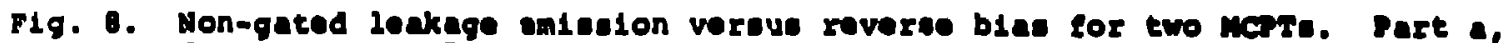
for a Varo MCPT ehow poorer uppreasion than for ITI serple, part b.

\section{Dynendo shuttering}

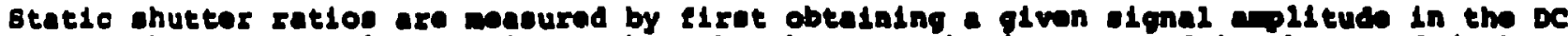
mode for a know optioel intanalty. Then the hutter tub is operated in the pated (Ac)

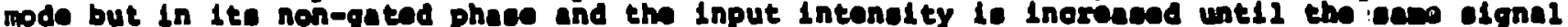
onplitude 10 obtained. The ratio of the two intensities, correoted for the difforenoe in $A C$ and $D C$ galne, is the ehutter ratio.

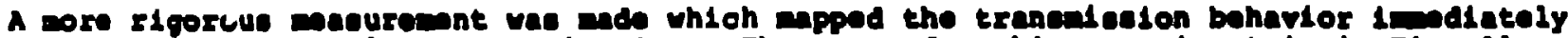

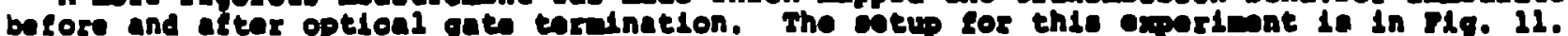

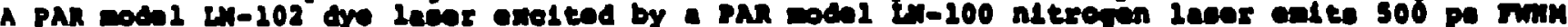

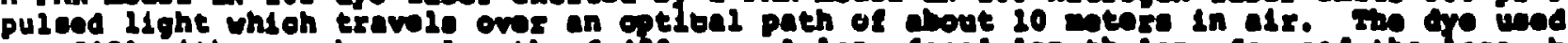

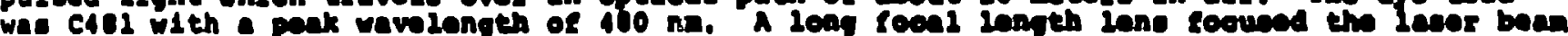

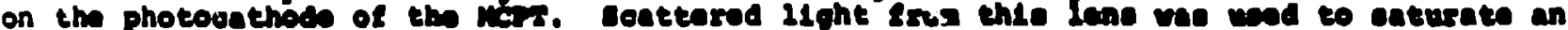

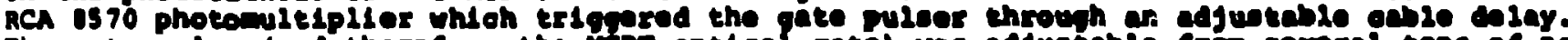

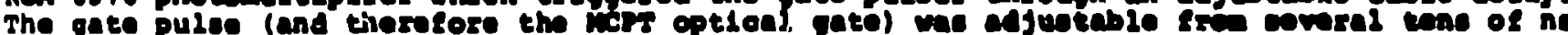

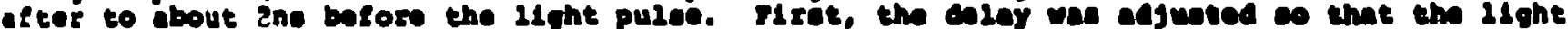

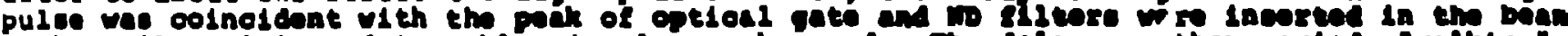

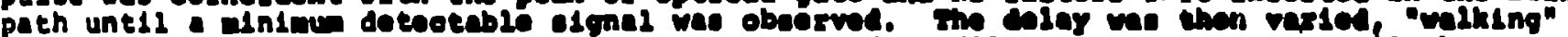

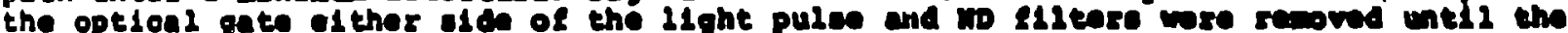

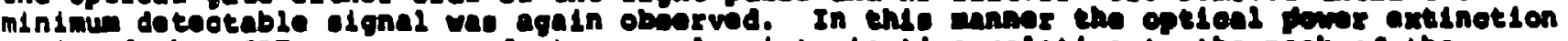

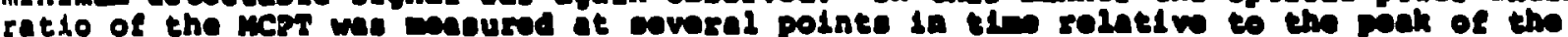

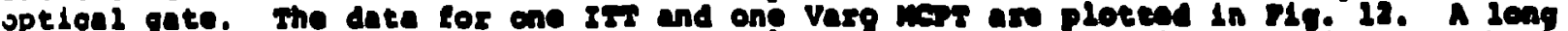

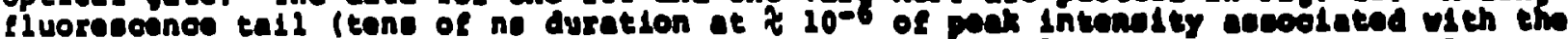

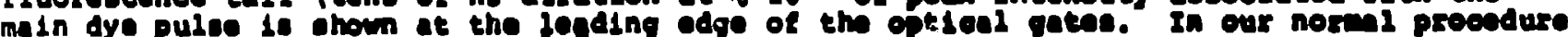

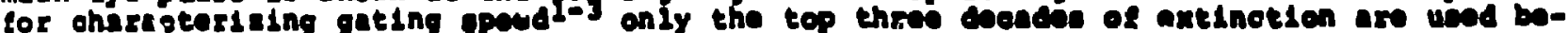

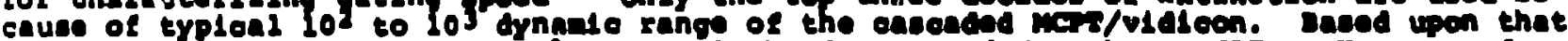

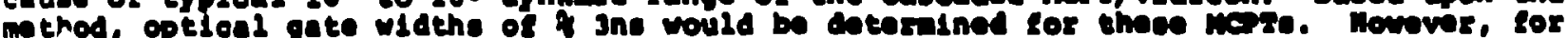

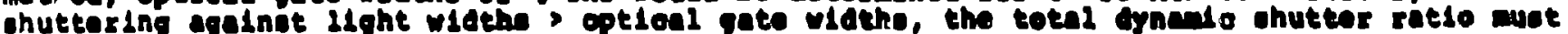
be inolued to soourately detine the total optien gate width.

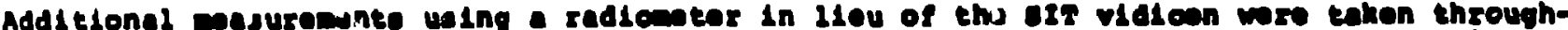

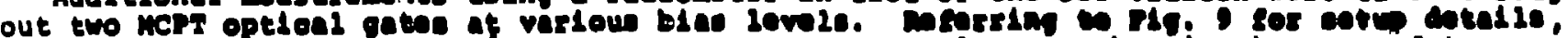

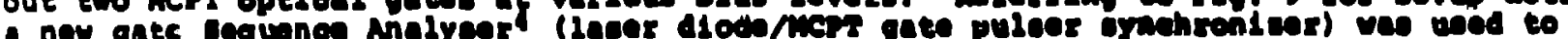

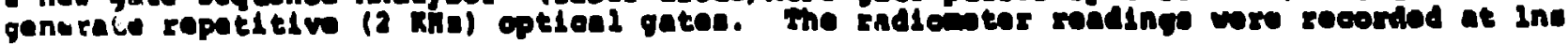




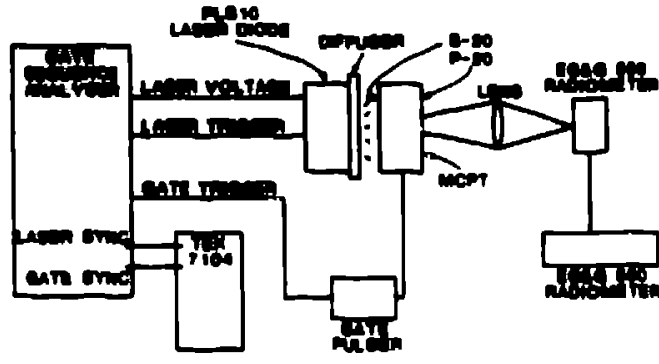

P1g. 9. Setup for measuring MCPT gain profiles throughout an opticel gate sequence a. functione of gate tim and gate bies.

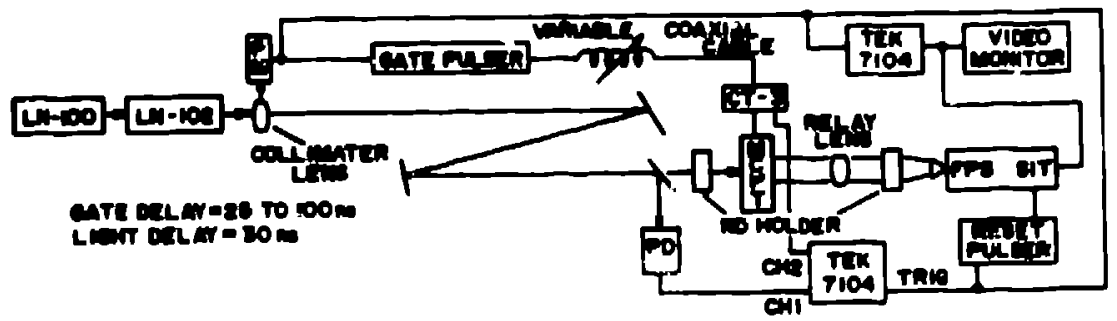

Fig. 11. Dynamic shutter ratio experimental setip.
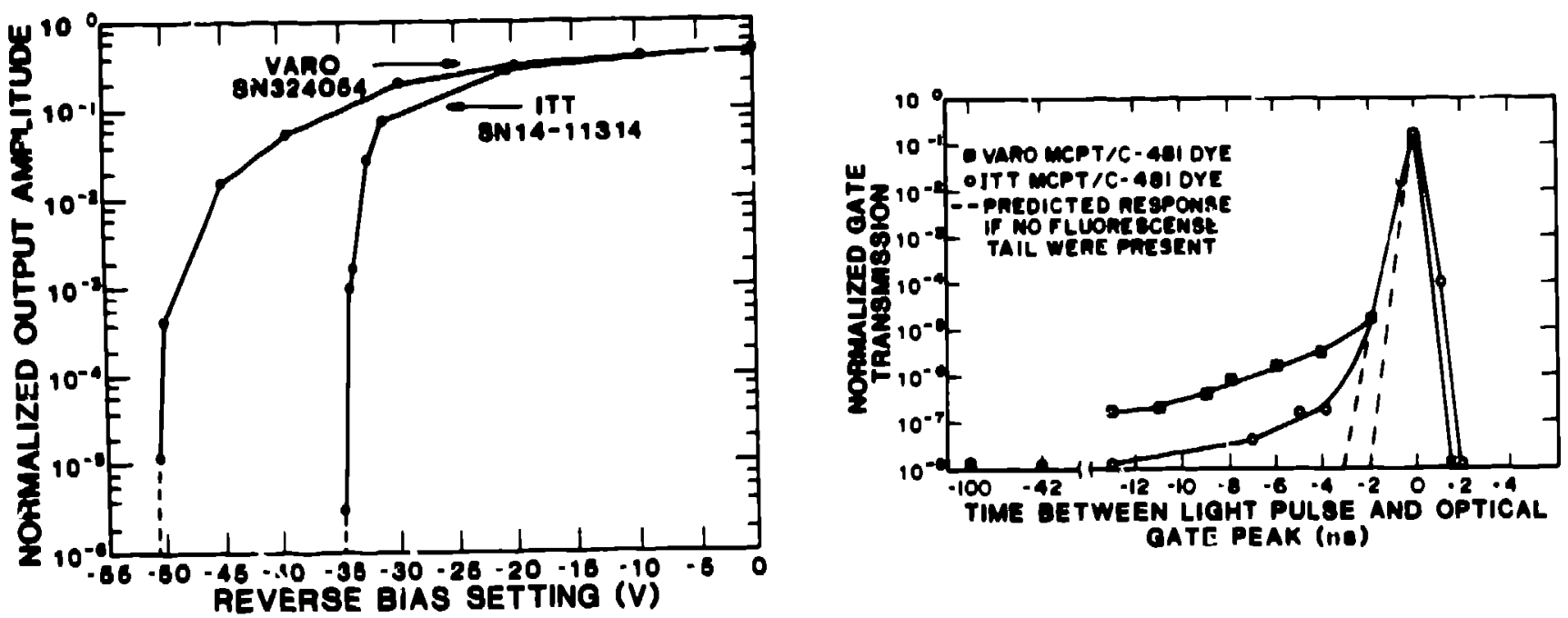

FJg. 10. MCPT gain dependence on reverse bias.

F1q. 12. Shutter ratio relative to center (zero) of optical gate.
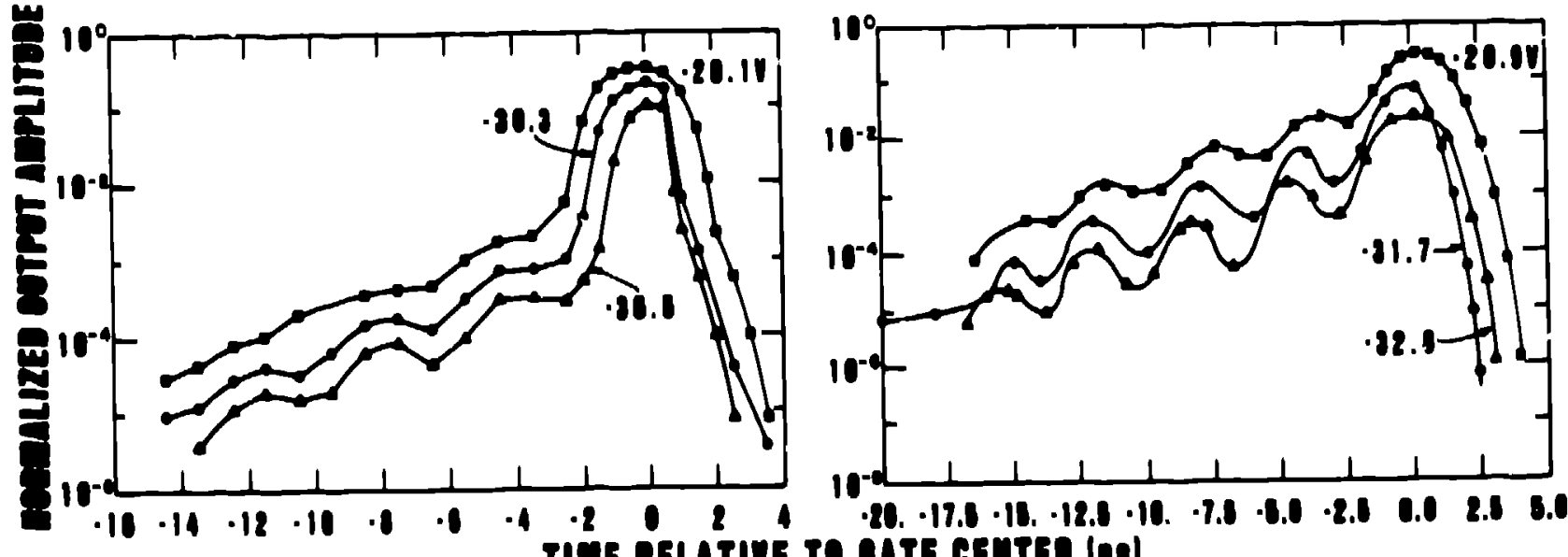

Fig. 13. Gain relative to center (zero) of optlcal gate for two MCPJu at three reverae biad levalis. 


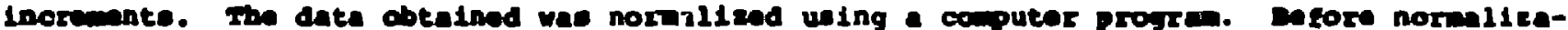

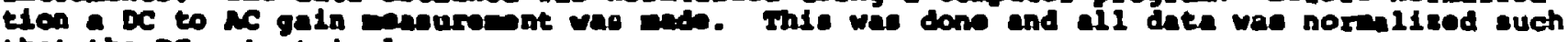
that the DC output 1s 1.

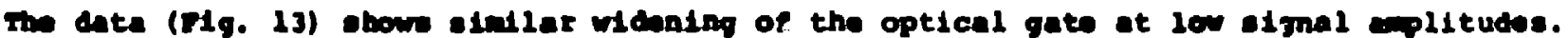
The ringing lo attributed to aleotriosi rolloctions from poor gate puleo tartination. The grpater canoitivity of the orr vidieon porileted traeking the gate traneriusion at lower

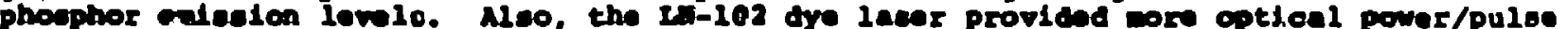
than the Plo-10 laser diods revulting in the longer plot in F1g. 12.

\section{Conolunions}

Opticel feodthrough eotabliches the lower linit of uoofulnose for more and stTV whon the light pules to equal to or chorter than the optied gate. For ilght puleos ionger than the gate, the feedthrovin clgmal integrated owr the tine duration of the light corpared with the gated eleavi integrated for tho gate duration glves a first approxidation effect of teodthrough.

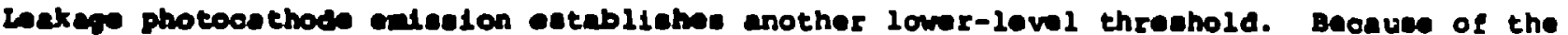
charing offect (of otetie and gated voltegas) betwen roverae and forvard blaces, ilynal 10ve1. within the gate very non-Iinarly a functions of (I) gated gain dwe to increasing forward voltag and (2) leakage gain Iros almultaneously decraaning reverae voltage. Out-

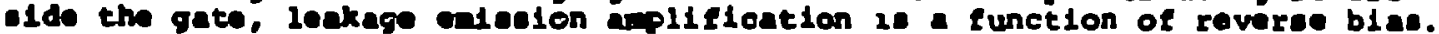

\section{Acknowledqunte}

Th. authors wish to thank John Bujnosek of Los Alaroe National Laboratory, Vanner Holmes

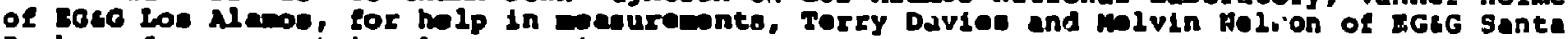
Darbara lor eupport in electrooptio masureasic apparatus, Terese Martines of Bgig Los Meos for lage proceenlng support, and John Cuny and Phillip Taylor of ITT for halp in opaclty maeuresonts and phosphor comting experimonts.

\section{merences}

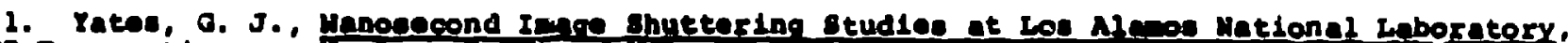

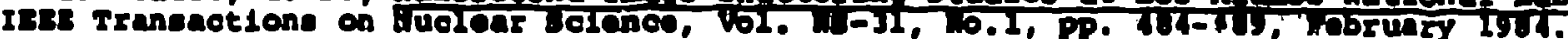

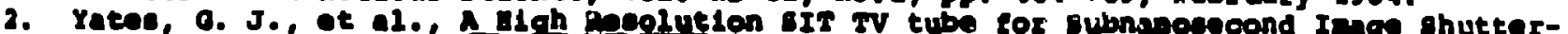

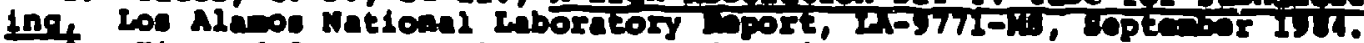

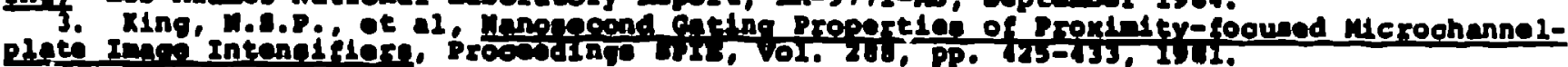

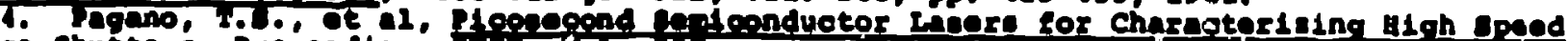

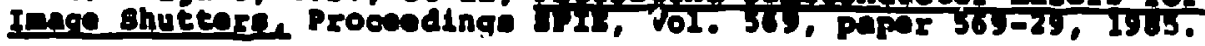

